\title{
Isolates of Rhizoctonia solani Can Produce both Web Blight and Root Rot Symptoms in Common Bean (Phaseolus vulgaris L.)
}

Suheidy Valentín Torres, Department of Biology, and María M. Vargas, Department of Biology, University of Puerto Rico, Mayagüez, PR 00681-9000; Graciela Godoy-Lutz, Instituto Dominicano de Investigaciones Agropecuarias y Forestales, Estación Experimental Arroyo Loro, Km 5, Carretera San Juan-Las Matas de Fafan, San Juan de la Maguana, Dominican Republic; Timothy G. Porch, United States Department of Agriculture-Agricultural Research Service, Tropical Agriculture Research Station, Mayagüez, PR 00680-5470; and James S. Beaver, Department of Agro-Environmental Science, University of Puerto Rico

\begin{abstract}
Valentín Torres, S., Vargas, M. M., Godoy-Lutz, G., Porch, T. G., and Beaver, J. B. 2016. Isolates of Rhizoctonia solani can produce both web blight and root rot symptoms in common bean (Phaseolus vulgaris L.). Plant Dis. 100:1351-1357.

In common bean (Phaseolus vulgaris L.), Rhizoctonia solani Kühn is an important pathogen causing web blight (WB) in the tropics, and it is also a soilborne pathogen causing root rot (RR) worldwide. This pathogen is a species complex classified into 14 anastomosis groups (AG). AG 1-IA, AG 1-IB, AG 1-IE, AG 1-IF, AG 2-2, and AG 4 have been reported to cause WB of the aboveground structures of the plant, while AG 4 and AG 2-2 have been associated with RR. There is limited information, however, concerning the ability of particular isolates of specific AG to cause both diseases in common bean. Nine $R$. solani isolates, including three AG 1 and three AG 4 WB isolates and three AG 4 RR isolates collected from both leaves and roots, respectively, of common bean in Puerto Rico, were used to evaluate the response of 12 common bean genotypes to WB inoculated using a detached-leaf method and to RR inoculated using a solution suspension of $R$. solani mycelia in the greenhouse. All $R$. solani

isolates were able to induce both $\mathrm{RR}$ and WB symptoms. RR readings were generally more severe than the WB readings. The RR isolate RR1 (AG 4) produced the most severe RR scores. A few bean lines had mean RR scores $\leq 4.4$ for specific $R$. solani isolates on a scale of 1 to 9 , with 1 representing resistant and 9 highly susceptible. However, all of the bean lines had mean RR scores $\geq 5.0$ when inoculated with the isolates RR1, RR2, and RR3, which were determined to be AG 4 in this study. Significant line-isolate interactions were observed for the WB and RR inoculations for the three planting dates, suggesting a differential response of the common bean lines to the pathogen. This genotypic interaction may require bean breeders and pathologists to monitor the virulence patterns of $R$. solani in specific growing environments, while the compatibility of specific $R$. solani isolates to both aerial and root tissue needs to be considered for disease control strategies.
\end{abstract}

Web blight (WB), caused by Rhizoctonia solani Kühn, is an important disease of common bean (Phaseolus vulgaris L.) in the humid lowland tropics of Central America and the Caribbean, and is also increasing in importance in Africa (Galvez et al. 1989; Godoy-Lutz et al. 2008; Montoya et al. 1997). This disease can occur at any stage of the bean-crop cycle, causing defoliation, which can lead to complete crop failure (Allen 1997; Galvez et al. 1989; Jung et al. 1996; Montoya et al. 1997; Singh 2001). $R$. solani is also a soilborne plant pathogen with a wide host range that causes significant root rot (RR) disease in common bean production regions worldwide. Because of its facultative parasitic ability, it can survive as a saprotroph in the soil (Otten et al. 2001; Zhao et al. 2005). Although pathogenicity on both shoot tissue and roots has been observed within single anastomosis groups (AG), there is little evidence to date of the ability of specific isolates within single AG of $R$. solani to cause disease in both roots and shoots of common bean. However, there is recent evidence of pathogens in other species, which have previously been defined as strictly shoot diseases, causing both root and aerial disease. In rice (Oryza sativa L.), root to shoot transmission of the rice blast fungus Magnaporthe grisea (T.T. Hebert) M. E. Barr indicates the role of both root and aerial plant parts in the disease life cycle (Sesma and Osbourn 2004). In sugar beet (Beta vulgaris L.; Vereijssen et al. 2004) and canola (Brassica napus L.; Sosnowski et al. 2001), the shoot pathogens Cercospora beticola Sacc. and Leptosphaeria maculans (Sowerby) P. Karst., respectively, have also been shown to cause disease in the root. Thus, the investigation of root and shoot host tissue compatibility of $R$. solani isolates will

Corresponding author: T. Porch; E-mail: timothy.porch@ars.usda.gov

Accepted for publication 29 February 2016.

http://dx.doi.org/10.1094/PDIS-11-15-1270-RE

(C) 2016 The American Phytopathological Society be important in informing approaches to both disease control and plant breeding strategies for this important pathogen.

Only multinucleate hyphae (Ceratobasidiales) of Rhizoctonia spp. have Thanatephorus cucumeris as their perfect stage (Tupac Otero et al. 2002). Although the $R$. solani complex has a wide range of host plants, both binucleate and multinucleate Rhizoctonia spp. appear to be crop specific (Mazzola 1997; Toda and Hyakumachi 2006). R. solani can spread by airborne basidiospores produced by the pathogen's teleomorph, T. cucumeris (A. B. Frank) Donk, and by rain-splashed sclerotia, infested soil debris, mycelial bridges between plants, and infected seed (Godoy-Lutz et al. 2003). Both the sclerotia (the asexual stage that can remain viable in soil for several years) and the basidia (the sexual stage) can initiate disease. Nonetheless, the diseases they cause differ in symptomology (Allen 1997; Galvez et al. 1989).

$R$. solani is a species complex currently classified into 14 AG based on hyphal fusion, cultural morphology, pathogenicity or virulence, and DNA homology (Godoy-Lutz et al. 2003; Harikrishnan and Yang 2004). Anastomosis refers to the hyphal fusion, which occurs only between isolates of the same AG. This grouping method classifies isolates according to their ability to anastomose with established AG tester isolates (Kuninaga et al. 2000). Subgroups differ in anastomosis frequency; physiological and morphological features; pathogenic characteristics; and biomolecular, biochemical, genetic, and DNA homology characteristics (Harikrishnan and Yang 2004; Kuninaga et al. 2000; Tewoldemedhin et al. 2006). Isolates within an AG may produce similar symptoms on a host and may also have similar host preferences (Dorrance et al. 2003). Some of these AG are known to cause WB while others are responsible for root, stem, or seed rots (Harikrishnan and Yang 2004). AG variability is the result of adaptation to different ecological areas but little is known about the regional predominance of specific AG types (Dorrance et al. 2003).

WB of common bean is reported to be caused by $R$. solani subgroups AG 1-IA, AG 1-IB, AG 1-IE, AG 1-IF, AG 2-2 (Godoy-Lutz et al. 2008), and AG 4 (Godoy-Lutz et al. 2003). AG 1 isolates include 
an aerial WB pathogen of common bean and other crops. Its sexual stage has been reported to occur in regions of Latin America and the Caribbean (Godoy-Lutz et al. 2008). In previous studies, AG 1 isolates developed water-soaked lesions and necrotic lesions after inoculation and were more virulent than AG 2 isolates (Godoy-Lutz et al. 2003). AG 1-IA isolates are reported to cause aerial blight of soybean and AG 1-IB causes WB of common bean; both subgroups can cause seed, root, and stem rot (Harikrishnan and Yang 2004). AG 1-IB was reported to have a high level of virulence in common bean (Montoya et al. 1997; Polanco 1993). Another subgroup, AG 1-IE, is found in the United States (Godoy-Lutz et al. 2008). Although AG 1-IE and AG 1-IF isolates cause similar symptoms on common bean, they can be easily distinguished by their cultural traits. Previous studies report that WB isolates collected in Puerto Rico (Montoya et al. 1997; Polanco 1993) and in Costa Rica (Galindo et al. 1982) also vary in levels of virulence in common bean.

AG 4 and AG 2-2 are the most common $R$. solani groups causing root and hypocotyl rot in common bean. They also cause dampingoff during early growth stages, and stem rot and RR during later stages (Balali and Kowsari 2004). R. solani AG 4 has been reported to cause RR of snap bean on the coastal plain of Georgia (Sumner and Bell 1994) while, as mentioned above, both AG 1-IA and AG 1-IB have been reported to cause RR in common bean (Harikrishnan and Yang 2004). Variability in virulence of RR disease caused by $R$. solani in bean has been demonstrated across geographical regions, indicating the diversity of the pathogen and the widespread nature of the disease (Galindo and Abawi 1982; Ohkura et al. 2009; PastorCorrales and Abawi 1988).

$R$. solani has a variable genetic composition which has aided its adaptation to diverse ecological niches and hosts (Godoy-Lutz et al. 2008). Various techniques have been developed for the qualitative and quantitative detection of $R$. solani. In recent years, nucleic-acid-based diagnostic techniques, such as those based on the polymerase chain reaction (PCR) and DNA probes, have been employed in the detection and quantification of the pathogen from infested soil and within infected roots (Sharon et al. 2006; Thornton et al. 2004). The ribosomal DNA (rDNA) internal transcribed spacer (ITS) regions have been useful in studying fungal isolates at the species level, as well as for linking anamorphs to their respective teleomorphs (Sillero et al. 2006). Genes coding for rDNA are highly conserved; thus, evaluating DNA sequence similarity of specific portions of the genome allows for a better understanding of the genetic relationships between taxonomic groups (Kuninaga et al.

Table 1. Common bean breeding lines and cultivars screened for web blight and root rot reactions in the greenhouse at the University of Puerto Rico, Mayagüez, PR

\begin{tabular}{|c|c|c|}
\hline Identification & Seed type & Pedigree \\
\hline PR0401-257 & Pink & $\begin{array}{l}\text { VAX 6//MUS83/BelNeb } \\
\text { RR1///DOR483/BAT93 }\end{array}$ \\
\hline PR0401-259 & Pink & $\begin{array}{l}\text { VAX 6//MUS83/BelNeb } \\
\text { RR1///DOR483/BAT93 }\end{array}$ \\
\hline PR0401-277 & Small red & VAX 6/EAP9503-32A \\
\hline PR0518-10 & Black & Negro Veracruz/PR9607-29 \\
\hline PR0518-15 & Black & Negro Veracruz/PR9607-29 \\
\hline PR0518-16 & Black & Negro Veracruz/PR9607-29 \\
\hline PR0650-27 & Purple & Amadeus 77//PI417662/Bibri \\
\hline PR0650-31 & Black & BAT 93/PI417622//VAX 6 \\
\hline PR0650-32 & Black & BAT 93/PI417622//VAX 6 \\
\hline PR0650-34 & Black & BAT 93/PI417622//VAX 6 \\
\hline PR0650-41 & Black & BAT 93/PI417622//VAX 6 \\
\hline Morales & White & Arroyo Loro/Don Silvio (DOR 482) \\
\hline Verano & White & DOR 364/WBB-20-1//Don Silvio/VAX 6 \\
\hline Amadeus 77 & Small red & Tio Canela 75/DICTA 105 \\
\hline Carrizalito & Small red & Tio Canela 75/DICTA 105 \\
\hline Talamanca & Black & $\begin{array}{l}\text { Cultivar from Costa Rica reported to have } \\
\text { moderate levels of resistance to web blight }\end{array}$ \\
\hline VAX 6 & Small red & $\begin{array}{l}\text { A769///A775//ICA } \\
\text { Pijao/G40001////XAN309. Bacterial blight } \\
\text { resistance derived from P. acutifolius } \\
\text { L. (G40001) }\end{array}$ \\
\hline
\end{tabular}

2000). Comparison of nucleic acid sequences for the $18 \mathrm{~S}$ rDNA, $28 \mathrm{~S}$ rDNA, and ITS sequences have revealed polymorphism between AG (Guillemaut et al. 2003). ITS sequence analysis has assisted in the classification of new isolates and in the differentiation and verification of previously defined subsets within AG (Guillemaut et al. 2003; Sharon et al. 2006, 2008). The ITS region 5.8S rDNA sequence is completely conserved across all AG. ITS 1 and ITS 2 rDNA sequences show greater variability between AG (Stojšin et al. 2007).

Progress in breeding bean for RR resistance has been limited because this trait is genetically complex and difficult to evaluate, lowering the efficiency of phenotypic selection (Román-Avilés and Kelly 2005). Although a few bean lines have intermediate levels of resistance to WB in the field (Montoya et al. 1997), there are currently no commercial bean varieties with high levels of resistance (Godoy-Lutz et al 2008); however, moderately resistant germplasm has been released recently (Beaver et al. 2012).

The objective of this study was to determine whether individual $R$. solani isolates could cause both root and aerial disease symptoms in common bean. Previous researchers have studied AG and their relationship to a specific disease but more information is needed concerning the ability of specific isolates within a single AG to cause more than one disease in common bean. This study focused on nine $R$. solani isolates, including three AG 1 and three AG 4 WB isolates and three AG 4 RR isolates collected from both leaves and roots and leaves, respectively, of common bean in Puerto Rico.

\section{Materials and Methods}

Fungal isolates. Previously characterized $R$. solani isolates AG 1-IA, AG 1-IF, AG 1-1E, WB1 (AG 4), WB2 (AG 4), and WB3 (AG 4) used in this study were provided by Dr. Graciela Godoy-Lutz (IDIAF, San Juan de la Maguana, Dominican Republic). These isolates originated from common bean leaves in Isabela, Puerto Rico (PR) that presented WB symptoms (Godoy-Lutz et al. 2008). Isolate AG 1-IE was provided by Dr. Myrna Alameda from the fungus collection maintained at the Alzamora Laboratory at the University of Puerto Rico, Mayagüez campus. Uncharacterized isolates of $R$. solani (RR1, RR2 and RR3) were isolated from common bean plants with typical $R$. solani RR symptoms from an RR nursery at the United States Department of Agriculture (USDA) Station in Isabela, PR that was previously characterized for its RR complex (Porch et al. 2014). Formerly characterized WB isolates and the RR isolates were first compared morphologically and microscopically. Anastomosis grouping of the isolates was performed by pairing the isolates on potato dextrose agar (PDA) medium to determine the presence or absence of hyphal fusion. The hyphae width, colony coloration, and sclerotia formation were evaluated for the three WB isolates and the three RR isolates.

The common bean tissue samples from individual plants with RR symptoms were processed in each evaluation by washing roots with tap water to remove soil and then cutting small pieces of roots and stems near visible areas of necrosis or lesions. The plant tissue was then surface sterilized in three treatments of $1 \mathrm{~min}$ each. The first solution was $20 \%$ commercial bleach, the second was $70 \%$ ethanol, and

Table 2. Root rot severity evaluation scale, modified from Büttner et al (2004) and Dorrance et al. (2003)

\begin{tabular}{ll}
$\begin{array}{l}\text { Severity } \\
\text { scale }\end{array}$ & \multicolumn{1}{c}{ Visible root damage percentage } \\
\hline 0 & No visible disease symptoms (root lesions or rot) \\
1 & 1 to $5 \%$ root surface with visible lesions ${ }^{\mathrm{a}}$ \\
2 & 5 to $10 \%$ root surface with visible lesions \\
3 & 10 to $25 \%$ root with visible lesions, dry-rot cankers, or both ${ }^{\mathrm{b}}$ \\
4 & 25 to $50 \%$ root with visible lesions, dry-rot cankers, or both \\
5 & 50 to $75 \%$ roots showing dry-rot cankers, damaged or rotted roots \\
6 & $>75 \%$ roots showing dry-rot cankers, damaged or rotted roots \\
7 & Preemergence damping-off and few if any roots ${ }^{\mathrm{c}}$ \\
\hline${ }^{\text {a }}$ Lesions = reddish-brown lesions on hypocotyls and roots, usually early dis- \\
ease development symptoms. \\
b Cankers = larger-sized sunken lesions, red in color. \\
${ }^{c}$ Hypocotyls girdled by coalescence of several cankers, resulting in preemer- \\
gence or postemergence damping off.
\end{tabular}


the final wash was with sterile distilled water. The excised root and stem segments were then transferred to petri dishes containing PDA (Bacto; Difco Laboratories) medium amended with 25\% lactic acid. Plates were incubated at $27^{\circ} \mathrm{C}$ for 7 days. Fungal colonies and hyphae growing from the root and crown segments were later purified by subculturing them in media-miser dishes containing V8 juice agar and PDA to promote fungal sporulation. Plates were then incubated for 4 to 5 days at $27^{\circ} \mathrm{C}$. The fungal isolates were identified based on cultural and morphological characteristics using taxonomic keys (Barnett and Hunter 2006; Watanabe 2002). R. solani isolates were identified morphologically based on their color and by the branching angle of their hyphae (Watanabe 2002), and identified to the species and AG level using AG-specific PCR primers (Godoy-Lutz et al. 2008).

The anastomosis grouping of RR1, RR2, and RR3 was verified by PCR. Nuclear rDNA and the 5.8S ribosomal-ITS regions (ITS-5.8SrDNA) were amplified using ITS-specific primers for AG 4 (4-F: TGGGGGGGAAG-GAACTTTATTGGAC and 4-R:CAGCTAATCC AAGAGGGCGG). For AG 1-IA, the primer pair sequences used were IA-F:CCTTATTTGGCAGGAGGGG and IA-R:GACTATTAGAA GCGGTTCA (Godoy-Lutz et al. 2008). The resulting PCR products of $370 \mathrm{bp}$ for AG 4 and $540 \mathrm{bp}$ for AG 1-IA were analyzed using electrophoresis on $1 \%$ agarose gels in Tris-borate-EDTA buffer with SYBR Safe DNA gel stain (Invitrogen) and with GeneRuler 1-kb DNA Ladder Plus (Fermentas Life Sciences) at $100 \mathrm{~V}$ for $1.5 \mathrm{~h}$. Fragments were viewed using a gel documentation system (Porch and Erpelding 2006).

Table 3. Analysis of variance of web blight severity of common bean breeding lines at $48 \mathrm{~h}$ after inoculation with nine isolates of Rhizoctonia solani

\begin{tabular}{lrccc}
\hline & & \multicolumn{3}{c}{ Mean squares $^{\mathbf{a}}$} \\
\cline { 3 - 5 } Source of variation & DF $^{\mathbf{b}}$ & $\mathbf{J u l y} \mathbf{2 0 0 7}$ & October 2007 $^{\text {January 2008 }}$ \\
\hline Line & 16 & $7.84^{*}$ & $5.60^{*}$ & $1.28^{*}$ \\
Isolate & 8 & $10.90^{*}$ & $61.13^{*}$ & $28.70^{*}$ \\
Line $\times$ isolate & 128 & $1.60^{*}$ & $1.97^{*}$ & $1.50^{*}$ \\
Error & 153 & 0.34 & 0.58 & 0.66 \\
Total & 305 & $\ldots$ & $\ldots$ & $\ldots$ \\
CV $(\%)^{\mathrm{c}}$ & $\ldots$ & 37.4 & 38.4 & 49.6 \\
LSD $(0.05)^{\mathrm{d}}$ & $\ldots$ & 0.9 & 1.2 & 1.3 \\
\hline
\end{tabular}

a Asterisk (*) indicates significant at $P<0.05$.

b Degrees of freedom.

$c$ Coefficient of variation.

d Least significant difference (LSD) (0.05) to compare means of specific lines and strains.
The rDNA-ITS-specific primers ITS1 and ITS4 were used to sequence previously uncharacterized USDA $R$. solani RR field isolates $\mathrm{RR} 1, \mathrm{RR} 2$, and RR3 as well as several previously characterized control isolates (AG 2-2, AG 1-IA, and AG 1-IE), as previously described (Godoy-Lutz et al. 2008; Prewitt et al. 2008). The amplified DNA was sequenced by SeqWright DNA Technology Services. The forward and reverse sequences were aligned with National Institute of Food and Agriculture Blast 2 Sequences.

WB greenhouse evaluations. Virulence of the nine $R$. solani isolates in causing WB was determined on 12 common bean breeding lines and five cultivars in a greenhouse. The experiments were planted at the University of Puerto Rico, Mayaguez Campus during the months of July and October 2007 and January 2008 (Table 1). The severity of WB reactions developed in the 12 genotypes was evaluated using the $R$. solani inoculum preparation and detachedleaf inoculation techniques, as previously described (Grosch et al. 2004; Kull et al. 2003; Priyatmojo el al. 2001; Takegami et al. 2004). To review the protocol briefly, plastic pots $(12 \mathrm{~cm}$ in diameter) were disinfested with sodium hypochlorite and filled with a sterilized mixture of peat moss and vermiculite. The planting medium was pasteurized as per Tewoldemedhin et al. (2006), and seed were disinfested with $20 \%$ bleach (final concentration of $1.05 \%$ sodium hypochlorite) for $10 \mathrm{~min}$ and $70 \% \mathrm{ETOH}$ for $5 \mathrm{~min}$, followed by two rinses with double-distilled (dd) $\mathrm{H}_{2} \mathrm{O}$. Samples of the disinfected seed were placed on PDA (Difco Laboratories) and incubated for 4 days at $25 \pm 2{ }^{\circ} \mathrm{C}$ to test the efficacy of the disinfection (Aziz et al. 1997; Balali and Kowsari 2004). Seed were planted in the substrate and, after emergence, plants were watered daily with tap water to avoid drought stress.

Once the first and third trifoliolate leaves of the common bean plants were fully expanded, approximately 4 weeks after planting, they were detached at the stem and evaluated as per the detachedleaf method, as described by Kull el al. (2003) and Takegami et al. (2004). In short, the leaves were labeled, placed in a moistened paper towel in plastic bags, organized in pans, and inoculated with the nine $R$. solani isolates. The inoculum was prepared as reviewed above and consisted of plugs of colonized agar (6 $\mathrm{mm}$ in diameter) from petri plates of cultures of $R$. solani WB isolates AG 1-IA, AG 1-IE, and AG 1-IF; three WB isolates collected from leaves with WB symptoms (WB1, WB2, and WB3); and three unknown isolates that were collected from roots with RR symptoms (RR1, RR2, and RR3). As per the protocol, the trifoliolates were placed in pans on benches, inoculated with $R$. solani disks, then incubated in the laboratory at $25 \pm$ $2{ }^{\circ} \mathrm{C}$. The leaves were then evaluated at set time points 24,48 , and $72 \mathrm{~h}$ after inoculation. A noninoculated leaflet was included as a control. The trifoliolate leaves were evaluated using a modified 1-to-9

Table 4. Mean web blight scores of common bean lines at $48 \mathrm{~h}$ after inoculation with nine isolates of Rhizoctonia solani

\begin{tabular}{|c|c|c|c|c|c|c|c|c|c|}
\hline Line & AG 1-IA & AG 1-IF & AG 4 (WB1) & AG 4 (WB2) & AG 4 (WB3) & AG 4 (RR1) & AG 4 (RR2) & AG 4 (RR3) & AG 1-IE \\
\hline PR0401-257 & 2.0 & 0.8 & 0.8 & 2.2 & 1.0 & 1.0 & 1.7 & 1.8 & 2.2 \\
\hline PR0401-259 & 1.0 & 0.7 & 1.2 & 2.5 & 0.6 & 1.7 & 1.5 & 1.0 & 1.8 \\
\hline PR0401-277 & 2.0 & 1.3 & 2.3 & 3.7 & 1.3 & 0.7 & 1.8 & 3.0 & 1.3 \\
\hline PR0518-10 & 1.8 & 1.5 & 1.7 & 3.7 & 2.0 & 0.7 & 3.0 & 1.8 & 2.2 \\
\hline PR0518-15 & 3.0 & 1.3 & 1.0 & 3.5 & 1.5 & 1.5 & 1.3 & 2.5 & 1.8 \\
\hline PR0518-16 & 1.5 & 2.7 & 1.7 & 3.7 & 1.8 & 0.3 & 2.7 & 2.7 & 1.2 \\
\hline PR0650-27 & 2.0 & 1.7 & 2.5 & 4.5 & 1.5 & 0.8 & 2.0 & 2.7 & 0.8 \\
\hline PR0650-31 & 1.2 & 0.5 & 1.3 & 2.5 & 1.0 & 1.2 & 1.5 & 1.7 & 1.8 \\
\hline PR0650-32 & 0.8 & 0.8 & 1.0 & 2.2 & 1.2 & 1.0 & 1.8 & 1.7 & 0.8 \\
\hline PR0650-34 & 1.7 & 1.3 & 1.0 & 2.5 & 1.7 & 1.5 & 2.5 & 1.2 & 2.2 \\
\hline PR0650-41 & 0.8 & 1.7 & 1.0 & 3.0 & 1.5 & 2.0 & 2.5 & 1.2 & 2.3 \\
\hline Morales & 1.5 & 2.2 & 2.2 & 2.8 & 1.3 & 1.3 & 2.0 & 1.3 & 2.7 \\
\hline Verano & 1.0 & 1.8 & 0.5 & 3.0 & 1.3 & 1.0 & 2.0 & 1.5 & 1.5 \\
\hline Amadeus 77 & 0.8 & 1.5 & 0.5 & 3.0 & 1.5 & 1.8 & 2.2 & 1.5 & 2.5 \\
\hline Carrizalito & 0.5 & 2.5 & 1.2 & 2.7 & 1.7 & 0.7 & 1.7 & 1.3 & 3.0 \\
\hline Talamanca & 1.3 & 1.8 & 1.0 & 3.2 & 3.3 & 1.8 & 1.5 & 1.2 & 2.5 \\
\hline VAX 6 & 1.8 & 1.3 & 1.3 & 2.8 & 0.8 & 1.5 & 1.8 & 1.7 & 2.5 \\
\hline
\end{tabular}

${ }^{a}$ Evaluated on a scale from 1 to 9 , where $1=$ no visible symptoms of the disease, $3=5$ to $10 \%$ foliage area with symptoms, $5=20$ to $30 \%$ foliage area with symptoms, $7=40$ to $60 \%$ foliage area with symptoms, and $9=>80 \%$ foliage area with symptoms (van Schoonhoven and Pastor-Corrales 1991 ). 
disease severity scale (van Schoonhoven and Pastor-Corrales 1991) to include a " 0 " rating indicating that the pathogen was not visible. Leaflets with severity scores from 1 to 3 were considered resistant or partially resistant, severity scores from 4 to 6 were considered intermediate, and scores $\geq 7$ were considered susceptible (Schmit and Baudoin 1992). A factorial arrangement of the 17 lines and the nine different fungal isolates was used in a completely randomized design with three replications. The experimental unit for WB was the trifoliolate leaf in each bean line evaluated. The two leaflets inoculated with Rhizoctonia disks were samples within the experimental unit.

RR greenhouse evaluations. RR greenhouse trials were planted during the months of October 2007, February 2008, and June 2008, while the same potted plants as those described above were used for the RR inoculation. To test the $R$. solani isolates for virulence, plants were inoculated after full expansion of the third trifoliolate leaf. The 12 breeding lines and five cultivars of common bean were inoculated with a mycelial suspension of single isolates of each of the same nine $R$. solan $i$ isolates. Thus, all nine isolates were individually evaluated against the set of common bean germplasm. The inoculation was conducted by dispensing at the soil line and near the hypocotyl, using a disposable pipette, $10 \mathrm{ml}$ of a mycelial suspension (inoculum preparation described below) of each of nine different $R$. solani isolates described in the WB inoculation above. A factorial arrangement of the 17 lines and the nine different fungal isolates was applied using a completely randomized design with three replications. The negative control was not inoculated with $R$. solani. The plants were kept in a greenhouse at the

Table 5. Analysis of variance of web blight severity evaluations of bean lines at $72 \mathrm{~h}$ after inoculation with nine isolates of Rhizoctonia solani

\begin{tabular}{lrccc}
\hline & & \multicolumn{3}{c}{ Mean squares $^{\mathbf{a}}$} \\
\cline { 3 - 5 } Source of variation & DF $^{\mathbf{b}}$ & $\mathbf{J u l y} \mathbf{2 0 0 7}$ & October 2007 $^{\text {January 2008 }}$ \\
\hline Line & 16 & $14.90^{*}$ & $4.00^{*}$ & $6.39^{*}$ \\
Isolate & 8 & $31.50^{*}$ & $124.52^{*}$ & $62.16^{*}$ \\
Line $\times$ isolate & 128 & $4.92^{*}$ & $2.05^{*}$ & $3.44^{*}$ \\
Error & 153 & 0.80 & 1.30 & 1.25 \\
Total & 305 & $\ldots$ & $\ldots$ & $\ldots$ \\
CV $(\%)^{\mathrm{c}}$ & $\ldots$ & 27.5 & 27.2 & 34.9 \\
LSD $(0.05)^{\mathrm{d}}$ & $\ldots$ & 1.4 & 1.8 & 1.8 \\
\hline
\end{tabular}

a Asterisk (*) indicates significant at $P<0.05$.

b Degrees of freedom.

c Coefficient of variation.

${ }^{\mathrm{d}}$ Least significant difference (LSD) (0.05) to compare means of specific lines and strains.
University of Puerto Rico, Mayagüez, PR until evaluation at 21 days after inoculation.

The inoculum for the RR assay was collected from $R$. solani grown on PDA in five petri dishes ( 95 by $15 \mathrm{~mm}$ ). $R$. solani isolates grown from 6-mm $R$. solani disks were transferred to PDA and incubated for 14 days at $27^{\circ} \mathrm{C}$ without light. The isolates were covered with aluminum foil and kept in the dark to simulate darkness in an underground environment (Büttner et al. 2004). After 14 days, the contents of the five petri cultures were macerated in a Waring blender with 1 liter of $\mathrm{ddH}_{2} \mathrm{O}$ (Büttner et al. 2004). The final concentration of the suspension was $10^{3}$ mycelial fragments $/ \mathrm{ml}$. A dilution plating technique was used to quantify the inoculum density (Paulitz and Schroeder 2005). The CFU were determined to estimate the number of viable infective units present per milliliter of the inoculum suspension, which consisted of five PDA plates inoculated with $R$. solani (Cappuccino and Sherman 1999). The $R$. solani AG $1-\mathrm{IA} 10^{-3}$ dilution $(1 \mathrm{ml})$ was added and distributed between 25 plates using the pour-plate technique. The pourplate technique is a simple method for estimating the concentration of viable propagules by sequential dilution of the original stock solution in tubes, then plating onto petri plates, with subsequent determination of CFU. The plates were incubated for 3 days at $27^{\circ} \mathrm{C}$. Colonies were then counted and multiplied by the dilution factor, which is the reciprocal of the dilution (Cappuccino and Sherman 1999). The inoculum concentration was then adjusted to $6 \times 10^{4} \mathrm{CFU} / \mathrm{ml}$ for the inoculation.

Root disease severity was visually rated using a modified 0-to-7 RR severity scale (Table 2) (Büttner et al. 2004; Dorrance et al. 2003). The experimental unit for RR was the pot containing a plant with or without Rhizoctonia inoculation. There were three replicates, and the experiment was repeated three times. To verify the presence of $R$. solani in the infected tissues and to confirm Koch's postulates, the root tips and the tissue nearest the observed stem lesions were excised, surface sterilized in $20 \%$ sodium hypochlorite for $4 \mathrm{~min}$ and $70 \%$ ETOH for $1 \mathrm{~min}$, followed by two rinses in $\mathrm{ddH}_{2} \mathrm{O}$ (Carling et al. 2002), then placed in PDA plates and incubated for 4 days at $27^{\circ} \mathrm{C}$. Later, the presence of $R$. solani was confirmed by observing the $R$. solani-like mycelium growing out of the infected pieces under a light microscope at $40 \times$ magnification.

Data analyses. Analysis of variance (ANOVA) for the WB and RR greenhouse evaluations was conducted using the STATISTIX statistical package (Analytical Software). A completely randomized design with three replicates was used. The factorial arrangement consisted of nine $R$. solani isolates and the 12 common bean genotypes. If treatment effects in the ANOVA were significant, least significant differences among means for each parameter were determined at $P=0.05$.

Table 6. Mean web blight scores of bean lines at $72 \mathrm{~h}$ after inoculation with nine isolates of Rhizoctonia solani ${ }^{\mathrm{a}}$

\begin{tabular}{|c|c|c|c|c|c|c|c|c|c|}
\hline Line & AG 1-IA & AG 1-IF & AG 4 (WB1) & AG 4 (WB2) & AG 4 (WB3) & AG 4 (RR1) & AG 4 (RR2) & AG 4 (RR3) & AG 1-IE \\
\hline PR0401-257 & 3.3 & 2.5 & 2.8 & 4.5 & 3.2 & 1.3 & 3.8 & 3.0 & 4.2 \\
\hline PR0401-259 & 2.3 & 1.8 & 1.7 & 4.0 & 2.7 & 2.3 & 3.2 & 2.8 & 4.0 \\
\hline PR0401-277 & 4.2 & 3.2 & 3.8 & 5.3 & 3.3 & 2.0 & 4.2 & 4.8 & 3.5 \\
\hline PR0518-10 & 3.3 & 5.0 & 2.8 & 5.3 & 3.8 & 2.7 & 4.3 & 2.3 & 4.8 \\
\hline PR0518-15 & 5.0 & 4.0 & 2.5 & 5.8 & 3.8 & 2.3 & 4.3 & 4.7 & 4.2 \\
\hline PR0518-16 & 2.7 & 4.7 & 3.0 & 6.2 & 3.5 & 1.8 & 5.0 & 6.3 & 3.2 \\
\hline PR0650-27 & 4.0 & 3.8 & 5.2 & 6.8 & 5.7 & 2.0 & 4.8 & 5.2 & 2.2 \\
\hline PR0650-31 & 2.2 & 3.5 & 3.3 & 4.2 & 3.3 & 2.8 & 3.2 & 3.0 & 4.5 \\
\hline PR0650-32 & 2.3 & 3.3 & 2.0 & 4.3 & 3.0 & 3.0 & 4.2 & 3.2 & 2.5 \\
\hline PR0650-34 & 3.2 & 3.0 & 2.5 & 4.3 & 4.3 & 2.7 & 4.2 & 2.8 & 4.2 \\
\hline PR0650-41 & 2.3 & 3.7 & 3.0 & 4.5 & 4.0 & 4.5 & 4.8 & 3.7 & 4.0 \\
\hline Morales & 2.8 & 4.2 & 4.0 & 4.3 & 3.3 & 3.7 & 3.3 & 3.2 & 4.3 \\
\hline Verano & 1.7 & 3.5 & 2.2 & 5.0 & 3.2 & 1.8 & 3.7 & 3.6 & 2.7 \\
\hline Amadeus 77 & 1.5 & 3.7 & 3.2 & 5.0 & 3.2 & 3.8 & 2.8 & 3.3 & 4.7 \\
\hline Carrizalito & 2.2 & 4.5 & 2.5 & 4.2 & 3.3 & 1.5 & 4.0 & 2.2 & 4.3 \\
\hline Talamanca & 2.7 & 3.7 & 3.2 & 4.7 & 4.7 & 2.9 & 3.2 & 3.3 & 4.2 \\
\hline VAX 6 & 3.2 & 2.7 & 2.8 & 4.2 & 2.8 & 4.8 & 3.0 & 3.8 & 4.2 \\
\hline
\end{tabular}

a Evaluated on a scale from 1 to 9 , where $1=$ no visible symptoms of the disease, $3=5$ to $10 \%$ foliage area with symptoms, $5=20$ to $30 \%$ foliage area with symptoms, $7=40$ to $60 \%$ foliage area with symptoms, and $9=>80 \%$ foliage area with symptoms (van Schoonhoven and Pastor-Corrales 1991 ). 


\section{Results}

Morphological and molecular rDNA-ITS analysis of uncharacterized $\boldsymbol{R}$. solani isolates. The WB and RR isolates were evaluated morphologically and microscopically. Anastomosis grouping of the isolates was performed by pairing the isolates on PDA medium to observe if hyphal fusion occurred, indicating that the three RR isolates were AG 4 . The hyphae width, colony coloration, and sclerotia formation were also evaluated for the three WB isolates and the three RR isolates. Young colonies of both WB and RR isolates were offwhite to cream color, and turned slightly brownish as they matured. None of these isolates formed sclerotia, nor did they grow abundant aerial mycelium as did the AG 1-IA, -IE, and -IF isolates. Thus, considering the cultural and morphological results, the three root isolates were tentatively classified as belonging to AG 4 .

In addition to the morphological assessment, molecular classification of the unknown isolates (RR1, RR2, and RR3) from infected common bean roots was used because selective media alone cannot discriminate between Rhizoctonia spp. and Rhizoctonia-like fungi, and a considerable level of taxonomic expertise is generally required (Thornton et al. 2004). Five PCR replications, using a specific ITS5.8S-rDNA region primer pair for AG 4, were conducted. The AG 4-specific primers amplified a region of approximately $370 \mathrm{bp}$, which

Table 7. Analysis of variance of root rot root rot scores of bean lines inoculated with nine isolates of Rhizoctonia solani

\begin{tabular}{|c|c|c|c|c|}
\hline \multirow[b]{2}{*}{$\begin{array}{l}\text { Source of } \\
\text { variation }\end{array}$} & \multirow[b]{2}{*}{$\mathbf{D F}^{\mathbf{b}}$} & \multicolumn{3}{|c|}{ Mean squares per plantinga } \\
\hline & & $\begin{array}{c}\text { October } \\
2007\end{array}$ & $\begin{array}{c}\text { February } \\
2008\end{array}$ & $\begin{array}{l}\text { June } \\
2008\end{array}$ \\
\hline Line & 16 & $10.80 *$ & $3.17 *$ & $2.99 *$ \\
\hline Isolate & 8 & $3.74 *$ & $2.01 *$ & $1.10^{*}$ \\
\hline Line $\times$ isolate & 128 & $2.86^{*}$ & $2.38 *$ & $0.67 *$ \\
\hline Error & & 0.55 & 0.60 & 0.26 \\
\hline Total & $(407,394,352)^{\mathrm{c}}$ & $\ldots$ & $\ldots$ & \\
\hline $\mathrm{CV}(\%)^{\mathrm{d}}$ & $\ldots$ & 13.18 & 13.79 & 8.55 \\
\hline $\operatorname{LSD}(0.05)^{\mathrm{e}}$ & $\ldots$ & 1.2 & 1.3 & 0.8 \\
\hline
\end{tabular}

a Asterisk (*) indicates significance at $P=0.05$.

${ }^{b}$ Degrees of freedom (DF).

c Total DF for the October 2007, February 2008, and June 2008 plantings, respectively.

${ }^{\mathrm{c}}$ Coefficient of variation.

${ }^{\mathrm{e}}$ Approximate least significant difference (LSD) (0.05) for comparison of means of specific lines and strains. confirmed the classification of root isolates RR1, RR2, and RR3 as AG 4. The previously characterized AG $4 \mathrm{WB}$ isolates were used as positive controls. This result was compared with the tester isolate AG 1-IA, which amplified a region of approximately $540 \mathrm{bp}$. Sequence alignment of rDNA using basidiomycete-specific primers ITS1 and ITS4 further confirmed that the three isolates RR1, RR2, and RR3 were AG 4 (analysis not shown).

WB greenhouse evaluations. Few disease symptoms were visible $24 \mathrm{~h}$ after inoculation and this was consistent for the three planting dates. Although the 1-to-9 scale (van Schoonhoven and Pastor-Corrales 1991) was used to evaluate disease severity, a value of zero was assigned to leaves that presented no sign of the pathogen on the leaf surface. This distinction was made because the presence of mycelia was observed throughout the period of evaluation on the leaf surface of some bean lines without the manifestation of disease symptoms. Other bean lines never showed mycelia growth on their leaf surfaces.

In the ANOVA of the evaluations conducted at $48 \mathrm{~h}$ after inoculation, significant line-isolate interactions were detected (Table 3). Nevertheless, lines were identified in the trials that consistently produced lower WB scores for specific isolates. PR0401-259 and PR0650-32 had the lowest WB scores at $48 \mathrm{~h}$ after inoculation when averaged over the three planting dates (Table 4). Mean WB scores for PR0401-259 ranged from 0.6 to 2.5 , whereas PR0650-32 had mean scores ranging from 0.8 to 2.2. Isolate WB2 (AG 4) produced the highest WB scores for both lines. The highest WB score for PR0401-259 at $48 \mathrm{~h}$ after inoculation (4.0) was observed in the January 2008 planting when inoculated with the RR isolate RR1 (AG 4). The highest severity score for PR0650-32 at $48 \mathrm{~h}$ after inoculation was 3.0, which occurred in the October 2007 and January 2008 plantings when inoculated with the RR isolates RR3 (AG 4) and WB isolates WB1 (AG 4) and WB2 (AG 4).

The readings taken at $72 \mathrm{~h}$ after inoculation provided the best separation of mean WB scores among the bean lines. Coefficients of variation in the ANOVA of the evaluations conducted at $72 \mathrm{~h}$ after inoculation were lower than the ANOVA of the readings taken at $48 \mathrm{~h}$ after inoculation (Table 5). Significant line-isolate interactions were detected in the ANOVA of the three trials, although bean lines were identified in the trials that consistently produced lower WB scores for specific isolates. PR0401-259 had the lowest WB scores for the greatest number of isolates (Table 6). PR0401-259 expressed resistance to AG 1-IA, AG 1-IF, WB1 (AG 4), and WB3 (AG 4), with overall WB severity scores ranging between 1.7 and 2.7 for each isolate; and it showed an intermediate resistance to WB2 (AG 4), with an overall WB severity score of 4.0. These results were consistent with observations from field trials conducted at the Isabela

Table 8. Mean root rot scores of bean lines inoculated with nine isolates of Rhizoctonia solani ${ }^{\mathrm{a}}$

\begin{tabular}{|c|c|c|c|c|c|c|c|c|c|}
\hline Line & AG 1-IA & AG 1-IF & AG 4 (WB1) & AG 4 (WB2) & AG 4 (WB3) & AG 4 (RR1) & AG 4 (RR2) & AG 4 (RR3) & AG 1-IE \\
\hline PR0401-257 & 4.3 & 4.9 & 6.2 & 5.9 & 5.5 & 4.6 & 5.4 & 4.7 & 6.1 \\
\hline PR0401-259 & 6.0 & 5.3 & 3.9 & 5.5 & 6.0 & 6.1 & 6.1 & 6.0 & 6.1 \\
\hline PR0401-277 & 4.3 & 5.4 & 5.3 & 6.0 & 4.8 & 6.1 & 5.6 & 6.5 & 4.9 \\
\hline PR0518-10 & 6.3 & 5.9 & 5.9 & 5.4 & 5.7 & 5.5 & 5.9 & 5.2 & 5.3 \\
\hline PR0518-15 & 6.0 & 4.9 & 5.2 & 4.8 & 6.4 & 5.9 & 6.9 & 6.4 & 5.3 \\
\hline PR0518-16 & 4.5 & 5.8 & 5.6 & 6.0 & 5.9 & 5.4 & 5.9 & 6.2 & 5.8 \\
\hline PR0650-27 & 4.2 & 4.8 & 5.9 & 5.5 & 6.1 & 5.5 & 5.1 & 5.7 & 5.3 \\
\hline PR0650-31 & 5.6 & 6.5 & 5.7 & 6.3 & 5.8 & 6.3 & 5.4 & 6.5 & 6.1 \\
\hline PR0650-32 & 5.7 & 5.9 & 4.4 & 5.7 & 6.1 & 5.8 & 5.0 & 6.2 & 5.6 \\
\hline PR0650-34 & 6.4 & 6.2 & 6.0 & 5.8 & 6.4 & 5.7 & 6.4 & 6.7 & 5.6 \\
\hline PR0650-41 & 6.2 & 6.6 & 6.3 & 5.5 & 5.2 & 6.1 & 6.2 & 6.0 & 5.8 \\
\hline Morales & 6.2 & 5.8 & 6.0 & 2.7 & 6.3 & 6.2 & 5.7 & 6.5 & 6.5 \\
\hline Verano & 6.3 & 6.2 & 6.0 & 6.3 & 5.8 & 6.4 & 5.9 & 6.3 & 6.4 \\
\hline Amadeus 77 & 6.0 & 5.9 & 6.2 & 6.1 & 4.9 & 5.7 & 5.8 & 5.2 & 6.0 \\
\hline Carrizalito & 5.4 & 5.6 & 6.5 & 5.8 & 5.7 & 6.2 & 6.0 & 5.0 & 6.1 \\
\hline Talamanca & 5.1 & 5.8 & 5.3 & 5.9 & 6.1 & 6.2 & 5.4 & 5.4 & 4.7 \\
\hline VAX 6 & 5.3 & 5.6 & 5.8 & 5.8 & 5.5 & 6.1 & 5.0 & 5.6 & 5.7 \\
\hline
\end{tabular}

a Evaluated on a scale from 0 to 7 , where $0=$ no visible symptoms of the disease; $1=1$ to $5 \%$ root surface with visible lesions; $2=5$ to $10 \%$ root surface with visible lesions; $3=10$ to $25 \%$ root with visible lesions, dry-rot cankers, or both; $4=25$ to $50 \%$ root with visible lesions, dry-rot cankers, or both; $5=50$ to $75 \%$ roots showing dry-rot cankers, damaged or rotted roots; $6=>75 \%$ roots showing dry-rot cankers, damaged or rotted roots; and $7=$ preemergence damping off and few, if any, roots; modified from Büttner et al. (2004) and Dorrance et al. (2003). 
Substation over a 3-year period, in which PR0401-259 had among the highest levels of resistance to WB. PR0401-259 was released in 2012 by the University of Puerto Rico and USDA Agricultural Research Service as a multiple-disease-resistant bean germplasm line (Beaver et al. 2012). Other lines that expressed useful levels of resistance to specific strains were 'Carrizalito' to RR1 (AG 4) and RR3 (AG 4), and PR0650-32 to AG 1-IE and WB3 (AG 4).

RR greenhouse evaluations. The same 12 bean genotypes were also screened for RR resistance using a mycelia suspension method (Büttner et al. 2004). The lines were infected with the same WB and RR isolates used in the previous evaluation. At 21 days after inoculation, the roots were harvested and scored using a 0-to-7 severity scale, where $0=$ no symptoms, $6=>75 \%$ roots showing dry-rot cankers and damaged or rotted roots, and $7=$ preemergence damping-off and few, if any, roots (Büttner et al. 2004; Dorrance et al. 2003).

There were significant line-strain interactions for the greenhouse trials conducted at different planting dates (Table 7). The majority of the lines had mean RR scores $\geq 5$.0 when inoculated with $R$. solani isolates (Table 8). The most severe RR symptoms, ranging from 50 to $75 \%$ of the total root area damaged, were caused by WB isolates WB1-3 (AG 4) and AG 1-IE (isolate from Isabela, PR). A few lines, however, expressed moderate levels of resistance to specific $R$. solani isolates. PR0401-259 had a mean RR score of 3.9 when inoculated with isolate WB1 (AG 4), which corresponds to 10 to $25 \%$ of root area damaged. Although the 'Morales' white bean had susceptible RR reactions to eight of the nine $R$. solani isolates, the line was resistant when roots were inoculated with isolate WB2 (AG 4).

\section{Discussion}

Based on the cultural, morphological, and molecular results, the three unknown RR isolates RR1, RR2, and RR3 were classified as AG 4.

The greenhouse evaluations of WB showed significant line-strain interaction, which may require bean breeders and pathologists to monitor the virulence patterns of $R$. solani in target environments. Differences in levels of WB resistance to specific strains among bean lines suggest that it may be possible to develop breeding lines with resistance to a greater number of $R$. solani isolates using crosses between different sources of resistance.

The WB evaluation also established that $R$. solani isolates from diseased tissue of plants with RR symptoms were capable of inducing WB symptoms on the leaf surface of common bean. The RR isolates demonstrated shoot pathogenicity similar to that of the WB isolates throughout the screenings conducted over three planting dates. The most virulent RR isolates were RR2 (AG 4) and RR3 (AG 4). The most virulent WB isolates were AG 1-IE, WB2 (AG 4), and WB3 (AG 4). Montoya et al. (1997) and Polanco (1993) also reported that WB isolates collected in Puerto Rico vary in levels of virulence on bean. In addition, climatic conditions can affect disease development. During the summer of 2010, conditions at Isabela were favorable for the development of WB, and a severe WB infection appeared in a bean nursery at the USDA Research Station, where WB had not been previously observed.

Differences were also observed in the level of virulence among the RR isolates (AG 4), where RR1 was the least virulent isolate. Balali and Kowsari (2004) suggest that heterokaryosis could directly influence AG 4 pathogenicity and that isolates which have heterokaryons with genetically diverse nuclei could result in more virulent AG 4 isolates. Other authors have acknowledged that most AG or subgroups of $R$. solani exhibit a wide range of virulence and genetic diversity, perhaps due to genetic and environmental factors (Farrokhi-Nejad et al. 2007; González et al. 2012; Lakshman et al. 2012; Strausbaugh et al. 2011).

In the greenhouse evaluations, a few of the entries in the trials, such as PR0518-10 and PR0518-15, had been previously selected in the field for RR resistance yet did not show high levels of resistance in this evaluation. It is possible that the inoculation procedure for RR was too severe to detect moderate levels of resistance; thus, future RR inoculations should consider producing inoculum at higher mycelia dilutions, reducing the amount of liquid inoculum added per plant, inoculating at different developmental stages, or reducing the time of disease incubation in the greenhouse. Results from the greenhouse evaluations suggest that a few of the bean lines have RR resistance to specific isolates of $R$. solani. These results are noteworthy because high levels of RR resistance are uncommon in common bean.

In addition, RR severity scores may increase as the ambient or greenhouse temperatures increase. Environmental conditions such as temperature can affect the rate and severity of disease development with Fusarium and Rhizoctonia RR (Buerkert and Marschner 1992; Román-Avilés and Kelly 2005). Also, environmental conditions and disease pressure can influence variations in disease expression (Büttner et al. 2004).

The greenhouse evaluations confirmed that WB and RR isolates were equally effective in causing RR symptoms. However, RR symptoms of AG 1-IA (WB) tended to be less severe than other isolates. Isolates RR1 (AG 4) and RR3 (AG 4) showed the highest RR scores.

This study has shown that individual strains of single AG of $R$. solani isolated from both aerial and root structures of common bean can cause both shoot and root disease symptoms, as has been shown in other systems (Sesma and Osbourn 2004; Sosnowski et al. 2001; Vereijssen 2004). This broad tissue compatibility to both the aboveground and belowground plant organs suggests that $R$. solani has the ability to overcome tissue-specific resistance mechanisms and the ability to infect under variable environmental conditions. This finding has broad implications for the control of RR and WB disease in common bean.

The breeding and selection of bean lines for either leaf or RR resistance to $R$. solani may not result in resistance to both WB (aerial) and RR (root) diseases. PR0401-259 showed resistance to WB disease when inoculated with several $R$. solani RR isolates but showed a susceptible RR reaction when inoculated with these same isolates (RR1, RR2, and RR3; Tables 6 and 8). Thus, evaluations for both WB and RR diseases will be required to achieve pyramided resistance. Due to potential variability in disease reactions and due to geographical distribution of the pathogen, common bean breeders should take into consideration $R$. solani subgroups when developing resistant cultivars (Coyne et al. 2003).

\section{Literature Cited}

Allen, D. J. 1997. Food legumes. Pages 85-90 in: Soilborne Diseases of Tropical Crops. R. J. Killocks and J. M. Waller, eds. CAB International University Press, Cambridge, UK.

Aziz, N. H., El-Fouly, M. Z., El-Essawy, A. A., and Khalaf, M. A. 1997. Influence of bean seedling root exudates on the rhizosphere colonization by Trichoderma lignorum for the control of Rhizoctonia solani. Bot. Bull. Acad. Sin. 38:33-39.

Balali, G. R., and Kowsari, M. 2004. Pectic zymogram variation and pathogencity of Rhizoctonia solani AG-4 to bean isolates in Isfahan, Iran. Mycopathologia 158:377-384.

Barnett, H. L., and Hunter, B. B. 2006. Pages 66-196 in: Illustrated Genera of Imperfect Fungi, 4th ed. American Phytopathological Society, St. Paul, MN.

Beaver, J. S., Zapata, M., Alameda, M., Porch, T. G., and Rosas, J. C. 2012 Registration of PR0401-259 and PR0650-31 dry bean germplasm lines. J. Plant Regist. 6:81-84.

Buerkert, A., and Marschner, H. 1992. Calcium and temperature effects on seedling exudation and root rot infection of common bean on an acid sandy soil. Plant Soil 147:293-303.

Büttner, G., Pfähler, B., and Märländer, B. 2004. Greenhouse and field techniques for testing sugar beet for resistance to Rhizoctonia root and crown rot. Plant Breed. 123:158-166.

Cappuccino, J. G., and Sherman, N. 1999. Microbiology: A Laboratory Manual, 5th ed. Benjamin/Cummings Science Publishing, Menlo Park, CA.

Carling, D. E., Baird, R. E., Gitaitis, R. D., Brainard, K. A., and Kuninaga, S. 2002 Characterization of AG-13, a newly reported anastomosis group of Rhizoctonia solani. Phytopathology 92:893-899.

Coyne, D. P., Steadman, J. R., Godoy-Lutz, G., Gilbertson, R., Arnaud-Santana E., Beaver, J. S., and Myers, J. R. 2003. Contributions of the bean/cowpea CRSP to management of bean diseases. Field Crops Res. 82:155-168.

Dorrance, A. E., Kleinhenz, M. D., McClure, S. A., and Tuttle, N. T. 2003 Temperature, moisture, and seed treatment effects on Rhizoctonia solani root rot of soybean. Plant Dis. 87:533-538.

Farrokhi-Nejad, R., Cromey, M. G., and Moosawi-Jorf, S. A. 2007. Determination of the anastomosis grouping and virulence of Rhizoctonia spp. associated with potato tubers grown in Lincoln, New Zealand. Pak. J. Biol. Sci. 10: 3786-3793. 
Galindo, J. J., and Abawi, G. S. 1982. Variability among isolates of Rhizoctonia solani associated with snap beans and soils in New York. Plant Dis. 66: 390-394.

Galindo, J. J., Abawi, G. S., Thurston, H. D., and Galvez, G. 1982. Characterization of Thanatephorus cucumeris isolates causing web blight of beans in Costa Rica. Turrialba 32:447-455.

Galvez, G. E., Mora, B., and Pastor-Corrales, M. A. 1989. Web blight. Pages 195-209 in: Bean Production Problems in the Tropics. H. F. Schwartz and M. A. Pastor-Corrales, eds. CIAT, Cali, Colombia.

Godoy-Lutz, G., Kuninaga, S., Steadman, J. R., and Powers, K. 2008. Phylogenetic analysis of Rhizoctonia solani subgroups associated with web blight symptoms on common bean based on ITS-5.8S rDNA. J. Gen. Plant Pathol. 74:32-40.

Godoy-Lutz, G., Steadman, J. R., Higgins, B., and Powers, K. 2003. Genetic variation among isolates of the web blight pathogen of common bean based on PCR-RFLP of the ITS-rDNA region. Plant Dis. 87:766-771.

González, N., Godoy-Lutz, G., Steadman, J. R., Higgins, R., and Eskridge, K. M. 2012. Assessing genetic diversity in the web blight pathogen Thanatephorus cucumeris (anamorph $=$ Rhizoctonia solani) subgroups AG 1-IE and AG 1-IF with molecular markers. J. Gen. Plant Pathol. 78:85-98.

Grosch, R., Schneider, J. H. M., and Kofoet, A. 2004. Characterization of Rhizoctonia solani anastomosis groups causing bottom rot in field-grown lettuce in Germany. Eur. J. Plant Pathol. 110:53-62.

Guillemaut, C., Edel-Hermann, V., Camporota, P., Alabouvette, C., RichardMolard, M., and Steinberg, C. 2003. Typing of anastomosis groups of Rhizoctonia solani by restriction analysis of ribosomal DNA. Can. J. Microbiol. 49:556-568.

Harikrishnan, R., and Yang, X. B. 2004. Recovery of anastomosis group of Rhizoctonia solani from different latitudinal positions and influence of temperatures on their growth and survival. Plant Dis. 88:817-823.

Jung, G., Coyne, D. P., Skroch, P. W., Nienhuis, J., Arnaud-Santana, E., Bokosi, J., Ariyarathne, H. M., Steadman, J. R., Beaver, J. S., and Kaeppler, S. M. 1996. Molecular markers associated with plant architecture and resistance to common blight, web blight, and rust in common beans. J. Am. Soc. Hortic. Sci. 121:794-803.

Kull, L. S., Vuong, T. D., Powers, K. S., Eskridge, K. M., Steadman, J. R., and Hartman, G. L. 2003. Evaluation of resistance screening methods for Sclerotinia stem rot of soybean and dry bean. Plant Dis. 87:1471-1476.

Kuninaga, S., Nicoletti, R., Lahoz, E., and Naito, S. 2000. Ascription of Nt-isolates of Rhizoctonia solani to anastomosis group 2-1 (AG-2-1) on account of rDNAITS sequence similarity. J. Plant Pathol. 82:61-64.

Lakshman, D. K., Alkharouf, N., Roberts, D. P., Natarajan, S. S., and Mitra, A. 2012. Gene expression profiling of the plant pathogenic basidiomycetous fungus Rhizoctonia solani AG 4 reveals putative virulence factors. Mycologia 104:1020-1035.

Mazzola, M. 1997. Identification and pathogenicity of Rhizoctonia spp. isolated from apple roots and orchard soils. Phytopathology 87:582-587.

Montoya, C. A., Beaver, J. S., Rodríguez, R., Miklas, P. N., and Godoy-Lutz, G. 1997. Heritability of resistance to web blight in five common bean populations. Crop Sci. 37:780-783.

Ohkura, M., Abawi, G. S., Smart, C. D., and Hodge, K. T. 2009. Diversity and aggressiveness of Rhizoctonia solani and Rhizoctonia-like fungi on vegetables in New York. Plant Dis. 93:615-624.

Otten, W., Hall, D., Harris, K., Ritz, K., Young, I. M., and Gilligan, C. A. 2001. Soil physics, fungal epidemiology and the spread of Rhizoctonia solani. New Phytol. 151:459-468.

Pastor-Corrales, M. A., and Abawi, G. S. 1988. Bean accessions with resistance to Rhizoctonia solani under field conditions in Colombia. Turrialba 38:87-92.

Paulitz, T. C., and Schroeder, K. L. 2005. A new method for the quantification of Rhizoctonia solani and $R$. oryzae from soil. Plant Dis. 89:767-772.

Polanco, T. 1993. Desarrollo de una metodología de investigación para la identificación de genotipos de habichuela resistente a la mustia hilachosa. M.S. thesis, University of Puerto Rico, Mayagüez, PR.

Porch, T. G., and Erpelding, J. E. 2006. Low-cost conversion of the Polaroid MD-4 land camera to a digital gel documentation system. J. Biochem. Biophys. Methods 67:1-5

Porch, T. G., Valentin, S., Estevez de Jensen, C., and Beaver, J. S. 2014. Identification of soil-borne pathogens in a common bean root rot nursery in Isabela, Puerto Rico. J. Agric. Univ. P. R. 98:1-14.
Prewitt, M. L., Diehl, S. V., McElroy, T. C., and Diehl, W. J. 2008. Comparison of general fungal and basidiomycete-specific ITS primers for identification of wood decay fungi. For. Prod. J. 58:66-71.

Priyatmojo, A., Escopalao, V. E., Tangonan, N. G., Pascual, C. B., Suga, H., Kageyama, K., and Hyakumachi, M. 2001. Characterization of a new subgroup of Rhizoctonia solani anastomosis group 1 (AG-1-ID), casual agent of necrotic leaf spot on coffee. Phytopathology 91:1054-1061.

Román-Avilés, B., and Kelly, J. D. 2005. Identification of quantitative trait loci conditioning resistance to Fusarium root rot in common bean. Crop Sci. 45: $1881-1890$

Schmit, V., and Baudoin, J. P. 1992. Screening for resistance to Ascochyta blight in populations of Phaseolus coccineus L. and P. polyanthus Greenman. Field Crops Res. 30:155-165

Sesma, A., and Osbourn, A. E. 2004. The rice leaf blast pathogen undergoes developmental processes typical of root-infecting fungi. Nature 431: 582-586.

Sharon, M., Kuninaga, S., Hyakumachi, M., Naito, S., and Sneh, B. 2008. Classification of Rhizoctonia spp. using rDNA-ITS sequence analysis supports the genetic basis of the classical anastomosis grouping. Mycoscience 49:93-114.

Sharon, M., Kuninaga, S., Hyakumachi, M., and Sneh, B. 2006. The advancing identification and classification of Rhizoctonia spp. using molecular and biotechnological methods compared with the classical anastomosis grouping. Mycoscience 47:299-316.

Sillero, J. C., Fondevilla, S., Davidson, J., Vaz Patto, M. C., Warkentin, T. D., Thomas, J., and Rubiales, D. 2006. Screening techniques and sources of resistance to rusts and mildews in grain legumes. Euphytica $147: 255-272$.

Singh, S. P. 2001. Broadening the genetic base of common bean cultivars: A review. Crop Sci. 41:1659-1675.

Sosnowski, M., Ramsey, M., Murray, G., Scott, E., and Wilmshurst, C. 2001. Symptoms of blackleg (Leptosphaeria maculans) on the roots of canola in Australia. Plant Pathol. 50:808.

Stojšin, V., Budakov, D., Jacobsen, B., Grimme, E., Bagi, F., and Jasnić, S. 2007. Identification of Rhizoctonia solani isolates from sugar beet roots by analyzing the ITS region of ribosomal DNA. Proc. Nat. Sci. Matica Srpska Novi Sad 113: 161-171.

Strausbaugh, C. A., Eujayl, I. A., Panella, L. W., and Hanson, L. E. 2011. Virulence, distribution and diversity of Rhizoctonia solani from sugar beet in Idaho and Oregon. Can. J. Plant Pathol. 33:210-226.

Sumner, D. R., and Bell, D. K. 1994. Survival of Rhizoctonia spp. and root diseases in a rotation of corn, snap bean, and peanut in microplots. Phytopathology 84 : $113-118$

Takegami, J. C., Beaver, J. S., Godoy-Lutz, G., Echávez-Badel, R., and Steadman, J. R. 2004. Inheritance of web blight resistance in common bean. J. Agric. Univ. P. R. 88:45-54

Tewoldemedhin, Y. T., Lamprecht, S. C., McLeod, A., and Mazzola, M. 2006. Characterization of Rhizoctonia spp. recovered from crop plants used in rotational cropping systems in the Western Cape province of South Africa. Plant Dis. 90:1399-1406.

Thornton, C. R., Groenhof, A. C., Forrest, R., and Lamotte, R. 2004. A one-step, immunochromatographic lateral flow device specific to Rhizoctonia solani and certain related species, and its use to detect and quantify $R$. solani in soil. Phytopathology 94:280-288.

Toda, T., and Hyakumachi, M. 2006. Heterokaryon formation in Thanatephorus cucumeris anastomosis group 2-2 IV. Mycologia 98:726-736.

Tupac Otero, J., Ackerman, J. D., and Bayman, P. 2002. Diversity and host specificity of endophytic Rhizoctonia-like fungi from tropical orchids. Am. J. Bot. 89:1852-1858.

van Schoonhoven, A., and Pastor-Corrales, M. A. 1991. Standard System for the Evaluation of Bean Germplasm. Centro Internacional de Agricultura Tropical (CIAT), Cali, Colombia.

Vereijssen, J., Schneider, H. J. M., and Termorshuizen, A. J. 2004. Possible root infection of Cercospora beticola in sugar beet. Eur. J. Plant Pathol. 110: 103-106.

Watanabe, T. 2002. Pictorial Atlas of Soil and Seed Fungi, Morphologies of Cultured Fungi and Key to Species. CRC Press, Boca Raton, FL.

Zhao, G., Ablett, G. R., Anderson, T. R., Rajcan, I., and Schaafsma, A. W. 2005. Inheritance and genetic mapping of resistance to Rhizoctonia root rot and hypocotyls rot in soybean. Crop Sci. 45:1441-1447. 